\title{
Research Paper \\ Effects of Perinatal and Neonatal Sodium Nitrite on Serum Levels of Uric Acid, Urea, Creatinine, and Tissue Structure of Rats' Offspring Kidneys
}

\author{
Razieh Sanjari ${ }^{1} \mathbb{1}^{*}{ }^{*}$ Seyyed Ebrahim Hosseini ${ }^{1}$ (1)
}

1. Department of Biology, Faculty of Science, Shiraz Branch, Islamic Azad University, Shiraz, Iran.

2. Department of Biology, Faculty of Science, Zand Institute of Higher Education, Shiraz, Iran.

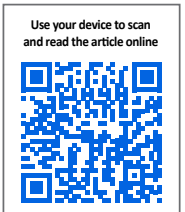

CFtration Sanjari R, Hoseini SE. [Effects of Perinatal and Neonatal Sodium Nitrite on Serum Levels of Uric Acid, Urea, Creatinine, and Tissue Structure of Rats' Offspring Kidneys (Persian)]. Quarterly of "The Horizon of Medical Sciences". 2021; 27(2):214-229. https://doi.org/10.32598/hms.27.2.1428.15

doi' $h$ ttps://doi.org/10.32598/hms.27.2.1428.15

Sodium nitrite, Perinatal, Neonatal Creatinine, Urea, Uric acid
Keywords:

\section{A B S T R A C T}

Received: 29 Mar 2020 Accepted: 06 Oct 2020 Available Online: 01 Apr 2021
Aims Sodium nitrite is a food preservative that can endanger human health. This study aimed to investigate the perinatal and neonatal effects of sodium nitrite on the functional and tissue structure of rats' offspring kidneys.

Methods \& Materials In this experimental study, 56 female rats were divided into seven groups ( $n=8)$ : control, perinatal and neonatal control groups, experimental groups 1 and 2 perinatal and neonatal (under oral treatment of doses of 90 and $180 \mathrm{mg} / \mathrm{kg}$ sodium nitrite during pregnancy and lactation). At the end of infancy, 8 offspring of rats were randomly selected from each group. After blood sampling, creatinine, urea, and uric acid levels were measured, and by extracting their kidneys, histopathological evaluation was performed.

Findings Perinatal and neonatal administration of 90 and $180 \mathrm{mg} / \mathrm{kg}$ sodium nitrite impaired renal tissue structure and significantly increased serum levels of creatinine, urea, and uric acid levels $(P<0.001)$ in rats' offspring compared to those in the control groups.

Conclusion Sodium nitrite consumption during pregnancy and lactation increases the serum levels of urea, uric acid, and creatinine by changing the tissue structure of the offspring kidneys.

\section{English Version}

\section{Introduction}

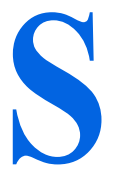

emi-finished meat products that are stored in the refrigerator have a limited shelf life [1]. Food products are usually spoiled by chemical changes or increased microbial load [2]. The presence of high concentrations of nitrate in aquatic environments, especially drinking water, leads to short-term and longterm adverse effects in the body and can cause diseases such as methemoglobinemia, cancer, and fetal disor- ders [3]. In addition to the effect of fat oxidation in reducing the quality of meat products, spoilage due to microbial contamination can create severe health risks to consumers. Accordingly, it seems that the use of appropriate substances with antibacterial and antioxidant activity is valuable and necessary to improve quality, increase durability, and at the same time prevent economic losses $[4,5]$. Nitrate and nitrite compounds are mainly used to stabilize the color of lean meat tissues, to flavor processed meat products, and to prevent the growth of spoilage microorganisms and subsequent food poisoning [6]. Nitrates and nitrites are the critical additives in producing processed meat products

\section{${ }^{*}$ Corresponding Author:}

Seyyed Ebrahim Hosseini, PhD.

Address: Department of Biology, Faculty of Science, Zand Institute of Higher Education, Shiraz, Iran.

Tel: +98 (917) 1183917

E-mail: ebrahhim.hossini@yahoo.cm 
that can damage blood vessels, liver, spleen, and other organs [7]. Despite the desirable properties of nitrites, they can react with amines and free amino acids in meat products under certain conditions and produce nitrogen amines [8]. Human contact with nitrate and nitrite compounds is mainly due to food consumption, especially vegetables, meat, and contaminated water [9]. When the $\mathrm{pH}$ of the stomach is acidic and intestinal bacteria are present in the intestine, nitrite compounds react quickly with secondary amines and amides, resulting in the production of the carcinogenic compounds N-nitroso [10].

Excessive use of food additives has greatly exposed humans to preservatives such as sodium nitrite [11]. Nitrites are at the center of oxidation and reduction reactions in the body, which can be oxidized to the highly biologically active radical nitric oxide and mainly to the nitrate anion [12]. Peroxynitrite (O-ONO) derived from compounds containing nitrite or nitrate can easily cross the phospholipid membranes of various cells and reacts with many molecules such as lipids, proteins, and DNA, and cause cell death by necrosis or induction of apoptosis [13]. Peroxynitrite and nitric oxide affect the cardiovascular system by different mechanisms and cause cell death and various tissue damages [14]. Sodium nitrite in different doses can reduce the thickness of the middle layer of the arteries by increasing the amount of nitric oxide in the blood and cause a variety of other disorders [15]. Consumption of sodium nitrite in drinking water in male and female rats causes hepatocellular degeneration and necrosis and hemosiderin deposition in the liver, spleen, and lymph nodes and hemolysis [16]. Nitrites and nitrates are both precursors of NO (Nitric Oxide) radicals that quickly pass through two phospholipid layers of the membrane by creating oxidative stress and producing ONOO- and reacting with many target molecules such as lipids, proteins, and DNA, and ultimately cell death through necrosis or apoptosis [17]. Nitrite-containing diets have been shown to adversely affect the mechanism of membrane cell proliferation within the vessels [18].

Most studies done on preservatives such as sodium nitrite have examined their effects on the tissue and functional structures of the consumers. So far, few studies (at least with the conditions governing this study) have been conducted in connection with the effects of perinatal and neonatal consumption of these compounds on the tissue and functional structure of children's kidneys. So the study of the effect of such substances on fetuses and infants is of particular importance. This study aimed to investigate the perinatal and neonatal effects of sodium nitrite on the tissue and functional structure of the kidneys of rats' offspring.

\section{Materials and Methods}

This experimental study was performed on 56 female Wistar rats in Islamic Azad University, Shiraz Branch, Shiraz City, Iran, in 2018. In this study, rats were divided into seven groups of 8: control group (untreated), perinatal and neonatal controls (treated with solvent), and experimental perinatal groups (treated with doses of 90 and $180 \mathrm{mg} / \mathrm{kg}$ sodium nitrite during pregnancy) and neonates (treated with doses of 90 and $180 \mathrm{mg} / \mathrm{kg}$ sodium nitrites during lactation). In this study, all prescriptions were performed by gavage. Eight adult male rats were used to conceive rats. This research protocol is based on the international law on laboratory animals and was approved by the University Ethics Committee IR.miau1395 1016. The rats of prenatal groups from the first day of pregnancy to the end of the period and rats of neonatal groups from the first day of birth to the end of lactation were prescribed sodium nitrite. At the end of lactation, 8 male offspring were randomly selected from each group, and after anesthesia with ketamine, their blood samples were taken from their hearts, and sufficient serum was prepared to measure urea, creatinine, and uric acid factors. Then, by separating their kidney organs and fixing them with $10 \%$ formalin for one week, tissue sections were prepared with the help of a tissue processor and a fully automatic microtome. Tissue sections were prepared, stained with hematoxylin-eosin, and then evaluated.

In this study, creatinine was measured by Jaffe/Fixed Rate or Kinetic method, and urea and uric acid were measured by Berthelot/Endpoint method using appropriate kits (made by ParsAzmoun Co., Iran). Finally, the data of this study were analyzed using ANOVA and Tukey statistical tests in SPSS v. 22. The significance of the data difference was considered at the level of $\mathrm{P}<0.05$.

\section{Results}

The results showed that sodium nitrite consumption at doses of 90 and $180 \mathrm{mg} / \mathrm{kg}$ during pregnancy (prenatal) in first-generation infants caused a significant increase in their serum urea, creatinine, and uric acid compared to the control group $(\mathrm{P}<0.001)$ (Tables 1 and 2).

The results also showed that sodium nitrite consumption at doses of 90 and $180 \mathrm{mg} / \mathrm{kg}$ during lactation (pre- 
Table 1. Mean and standard deviation of renal parameters in offspring of prenatal groups

\begin{tabular}{|c|c|c|c|}
\hline \multirow{2}{*}{ Group } & \multicolumn{3}{|c|}{ Mean \pm SD } \\
\hline & Uric Acid (mg/dL) & Creatinine (mg/dL) & BUN (mg/dL) \\
\hline Healthy control & $3.42 \pm 1.29$ & $0.398 \pm 0.066$ & $17.32 \pm 0.952$ \\
\hline Prenatal control & $3.30 \pm 0.33$ & $0.301 \pm 0.069$ & $17.38 \pm 1.076$ \\
\hline Prenatal + sodium nitrite 90 mg/kg & $5.20 \pm 0.49$ & $0.426 \pm 0.045$ & $38.65 \pm 4,791$ \\
\hline Prenatal + sodium nitrite $180 \mathrm{mg} / \mathrm{kg}$ & $5.65 \pm 1.14$ & $0.492 \pm 0.033$ & $39.40 \pm 6.759$ \\
\hline
\end{tabular}

natal) in rats' offspring caused a significant increase in their serum urea $(\mathrm{P}<0.003)$, creatinine, and uric acid compared to the control group $(\mathrm{P}<0.001)$ (Tables 3 and 4). Also, the results of histological studies showed that sodium nitrite consumption during pregnancy and lactation causes a lot of damage to the structure of rats' offspring renal tissues, such as congestion and diffuse bleeding, damage to the structure of proximal and distal convoluted tubules, dilation, and increase the space around the Bowman capsule, glomerular atrophy, and inflammation around the tubules as well as tubular damage (Figures 1, 2, 3, 4, \& 5).

\section{Discussion}

The results of this study showed that sodium nitrite consumption during pregnancy and lactation increases the serum levels of uric acid, urea, and creatinine by damaging the renal tissue structure. These results are consistent with the findings of Rammesh et al. as well as Ramezani Norouzani et al. [18, 19]. Stokes et al. reported that sodium nitrite consumption as a soluble in drinking water increased the amount of nitrite and nitrate in plasma, heart, liver, and kidney [20]. Sodium nitrite causes oxidative stress in the body and produces peroxynitrite (ONOO-), which passes freely through two phospholipid layers of the membrane and reacts with many target molecules such as lipids, proteins, and DNA, and this ultimately leads to cell death through the processes of necrosis and apoptosis [21]. Therefore, in the present study, nitrite compounds may have been transferred to fetuses and neonates of rats through placenta and milk, respectively, and through the above processes caused damage to the renal tissue structure and ultimately increased serum levels of uric acid, urea, and creatinine. It has also been shown that

Table 2. Results of ANOVA test to evaluate the effect of sodium nitrite with different doses on renal parameters in rats' offspring of prenatal groups

\begin{tabular}{|c|c|c|c|c|c|c|}
\hline \multicolumn{2}{|c|}{ Factors } & \multirow{2}{*}{$\begin{array}{c}\text { Sum of Squares } \\
1587.452\end{array}$} & \multirow{2}{*}{$\frac{\mathbf{d f}}{3}$} & \multirow{2}{*}{$\begin{array}{c}\text { Mean of Squares } \\
529.151\end{array}$} & \multirow{2}{*}{$\begin{array}{c}\mathbf{F} \\
29.933\end{array}$} & \multirow{2}{*}{$\begin{array}{c}\text { The Significance Level } \\
0.001\end{array}$} \\
\hline & Between groups & & & & & \\
\hline \multirow[t]{3}{*}{ Urea } & Within group & 494.977 & 28 & 17.678 & & \\
\hline & Total & 2082.429 & 31 & & & \\
\hline & Between groups & 0.044 & 3 & 0.015 & 4.654 & 0.001 \\
\hline \multirow[t]{3}{*}{ Creatinine } & Within group & 0.087 & 28 & 0.003 & & \\
\hline & Total & 0.131 & 31 & & & \\
\hline & Between groups & 18.200 & 3 & 6.067 & 7.256 & 0.001 \\
\hline \multirow[t]{2}{*}{ Uric acid } & Within group & 23.405 & 28 & 0.836 & & \\
\hline & Total & 41.606 & 31 & & & \\
\hline
\end{tabular}


Table 3. Mean and standard deviation of renal parameters in offspring of rats of neonatal groups

\begin{tabular}{|c|c|c|c|}
\hline \multirow{2}{*}{ Group } & \multicolumn{3}{|c|}{ Mean \pm SD } \\
\hline & Urea (mg/dL) & Creatinine (mg/dL) & Uric acid (mg/dL) \\
\hline Healthy control & $5.42 \pm 1.29$ & $0.39 \pm 0.06$ & $17.32 \pm 0.95$ \\
\hline Neonatal control & $2.47 \pm 1.31$ & $0.30 \pm 0.07$ & $23.93 \pm 13.59$ \\
\hline Neonatal + sodium nitrite 90 mg/kg & $5.7 \pm 1.95$ & $1.36 \pm 0.03$ & $37.23 \pm 11.93$ \\
\hline Neonatal + sodium nitrite 180 mg/kg & $5.19 \pm 0.93$ & $1.46 \pm 0.04$ & $39.26 \pm 10.59$ \\
\hline
\end{tabular}

Table 4. Results of 1-way analysis of variance to evaluate the effect of sodium nitrite with different doses on renal parameters in offspring of rats in neonatal groups

\begin{tabular}{|c|c|c|c|c|c|c|}
\hline \multicolumn{2}{|c|}{ Factors } & Sum of Squares & df & Mean of Squares & $\mathbf{F}$ & The Significance Level \\
\hline \multirow{3}{*}{ BUN } & Between groups & 1958.166 & 3 & 652.722 & 5.927 & 0.003 \\
\hline & Within group & 3038.708 & 28 & 110.132 & & \\
\hline & Total & 5041.875 & 31 & & & \\
\hline \multirow{3}{*}{ Creatinine } & Between groups & 0.109 & 3 & 0.036 & 11.520 & 0.001 \\
\hline & Within group & 0.089 & 28 & 0.003 & & \\
\hline & Total & 0.198 & 31 & & & \\
\hline \multirow{3}{*}{ Uric acid } & Between groups & 53.858 & 3 & 17.953 & 11.081 & 0.001 \\
\hline & Within group & 45.363 & 28 & 1.620 & & \\
\hline & Total & 99.221 & 31 & & & \\
\hline
\end{tabular}

Quarterly of

The Horizon of Medical Sciences

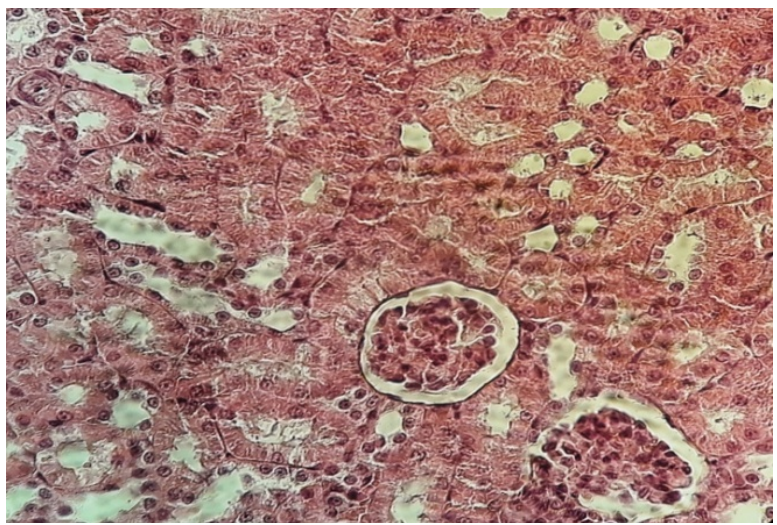

Figure 1. Normal kidney tissue in the control group

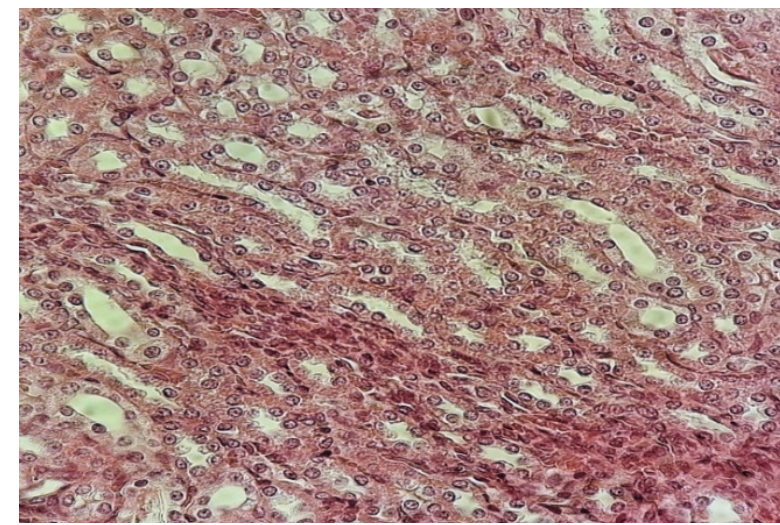

Quarterly of

The Horizon of Medical Sciences

Pathological changes in the malpighian body, glomeruli, surrounding space Bowman and tubule capsules proximal and distal were not seen in the pictures above. Hematoxylin-eosin staining. Magnification: x40 

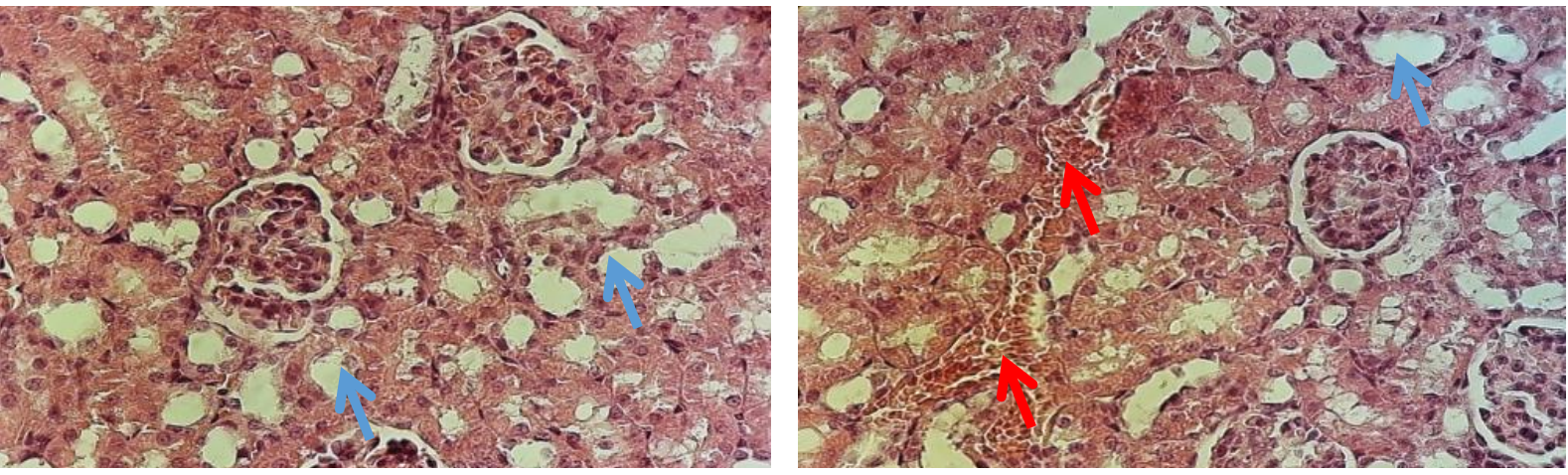

Quarterly of

The Horizon of Medical Sciences

Figure 2. Photomicrograph prepared from the experimental group of prenatal dose $90 \mathrm{mg} / \mathrm{kg}$ shows the results of moderate tissue damage in these two images

In both images, there are signs of diffuse bleeding (red arrow indicates the presence of red blood cells). Also, damage to the structure of convoluted tubules proximal and distal is shown in the pictures (blue arrow). Hematoxylin-Eosin staining. Magnification of x40.

the kidney, as the main site of filtration and one of the detoxification sites in the body, is directly affected by various drugs, and the metabolites produced by the toxins and studies have shown that damage to the renal parenchyma increases the serum concentrations of nitrogen, Blood Urea Nitrogen (BUN), creatinine, and uric acid [22]. Consistent with the histopathological results, Ashrafy et al. reported that a nitrate-containing diet causes microscopic lesions in the kidney's tissue structure, including hyperemia, cell swelling, and necrosis with moderate to severe renal cell resorption [24]. Consistent with this study's results, another study showed that the consumption of sodium nitrite in drinking water in male and female rats causes hepa- tocyte degeneration and necrosis and hemosiderin deposition in the liver, kidney, spleen, and lymph nodes and hemolysis [25]. Besides, Mohseni Kouchesfahani et al. showed that whenever renal function decreases, creatinine, urea, and uric acid levels in the blood increase [26].

On the other hand, the present study results showed that sodium nitrite treatment causes damage to the renal tissue structure, especially in renal glomeruli of animals. Therefore, the increase in serum urea, uric acid, and creatinine in these animals is probably due to the destructive effects of sodium nitrite on the kidneys' tissue structure. Recent research has clearly shown that

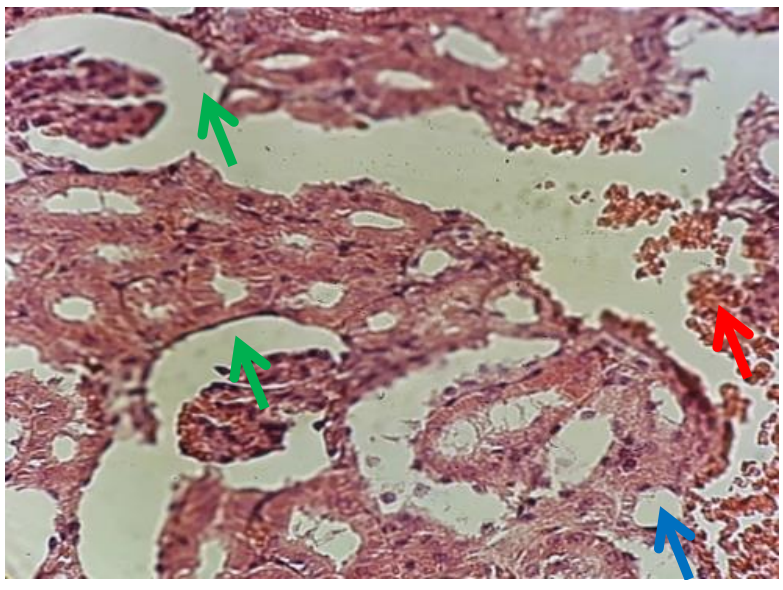

tissue damage in these two images

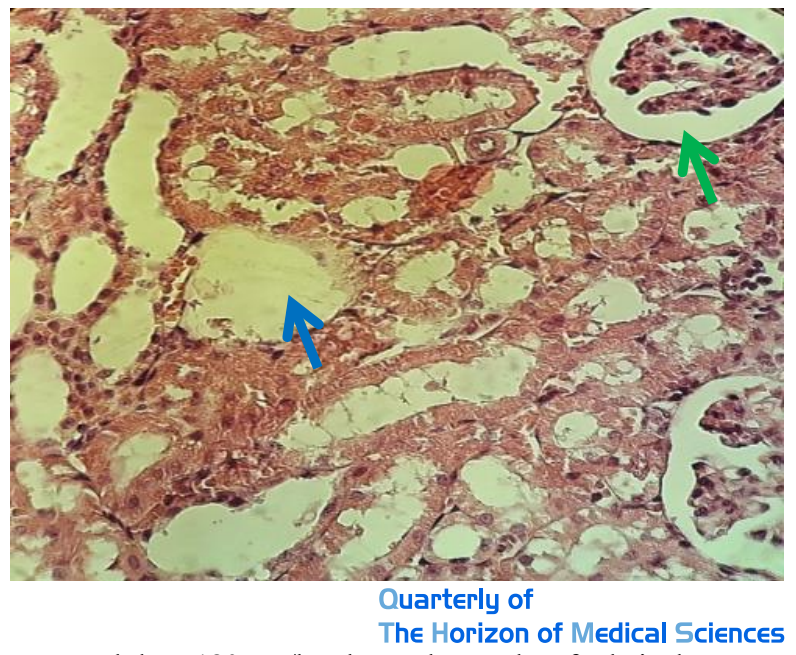

The Horizon of Medical Sciences

Signs of diffuse bleeding (red arrow). Also, severe damage to the structure of convoluted tubules proximal and distal is shown in the pictures (blue arrow). Dilation and enlargement of the space around the Bowman's capsule (green arrow) and the presence of glomerular atrophy and inflammation around the tubules were seen. Hematoxylin-Eosin staining. Magnification of $x 40$. 

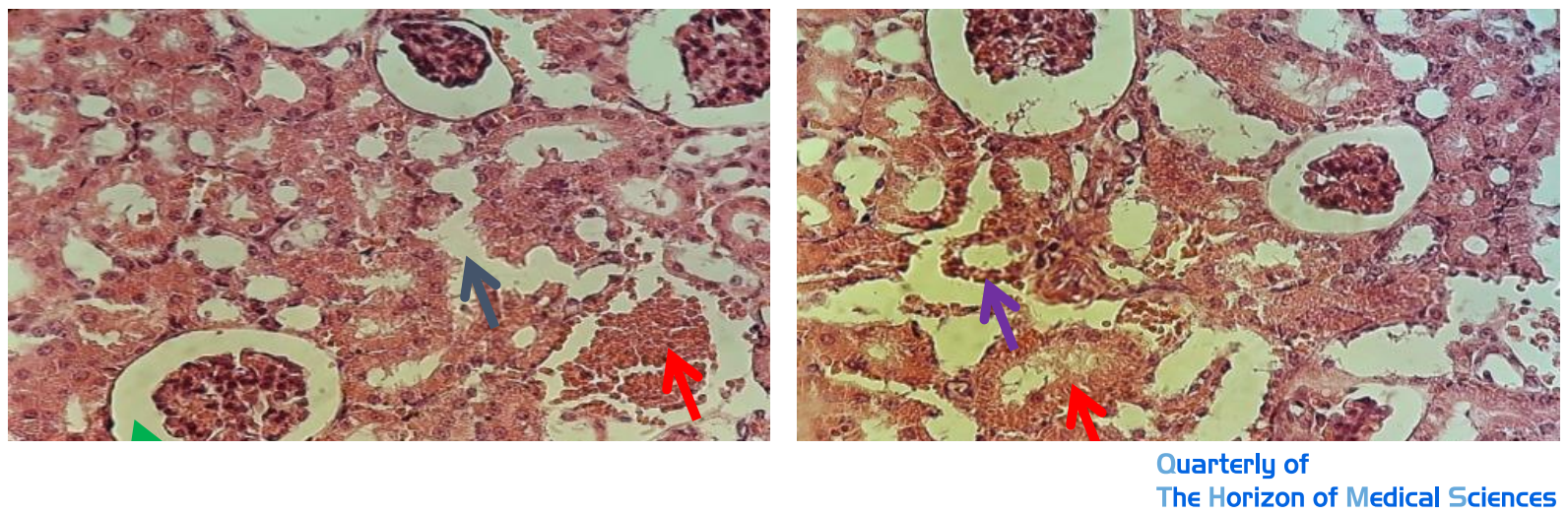

Figure 4. Photomicrograph prepared from the experimental group neonatal dose of $90 \mathrm{mg} / \mathrm{kg}$ : Observations show tissue damage in this group, which can be seen in the above images

Bleeding (red arrow), damage to the structure of convoluted tubules proximal and distal (blue arrow), and increased space around the Bowman capsule (green arrow), and inflammation (purple arrow) are seen. Hematoxylin-Eosin staining. Magnification x40
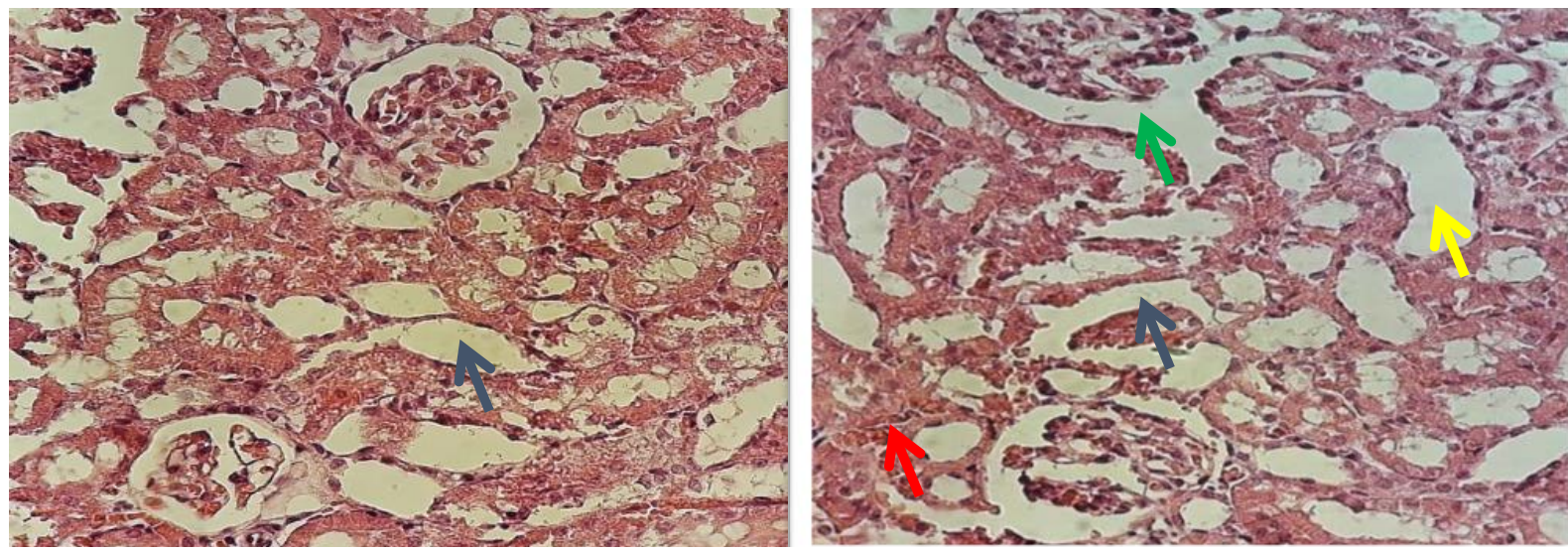

Quarterly of

The Horizon of Medical Sciences

Figure 5. Photomicrograph prepared from the experimental group neonatal dose of $180 \mathrm{mg} / \mathrm{kg}$ : as shown in the pictures, severe tissue damage can be seen in this group

Bleeding (red arrow), congestion and tubular injury (blue arrow), severe damage to the convoluted tubules (yellow arrow) can be seen in the images taken from this group. Hematoxylin-Eosin staining. Magnification x40.

nitric oxide can be produced directly from nitrite and impair blood flow to muscles and a greater extent, to other tissues, including the kidneys [27]. One study showed that excess nitrate in drinking water causes disorders in developing various organs of the body, including the fetal liver during pregnancy [28]. The present study had limitations such as high mortality of pregnant rats and their offspring treated with sodium nitrite and their offspring.

\section{Conclusion}

The results of this study showed that sodium nitrite consumption during pregnancy and lactation causes bleeding and destruction of kidney tissues, cell death, and loss of renal nephrons and possibly increases the serum level of renal factors (creatinine, uric acid, and urea) in the offspring of rats.

\section{Ethical Considerations}

\section{Compliance with ethical guidelines}

This study was approved by the Ethics Committee of the Shiraz Branch, Islamic Azad University, Shiraz, (Code: IR.MIAU1395.1016). In this study, all the rights of laboratory animals for human use were observed according to the international protocols of care and use of laboratory animals and was approved by the University Ethics Committee under the number. 


\section{Funding}

This research did not receive any grant from funding agencies in the public, commercial, or non-profit sectors.

Authors' contributions

Both authors contributed equally in all study procedures.

Conflicts of interest

The authors declared no conflict of interest.

Acknowledgements

The authors of the article must appreciate and thank the esteemed colleagues of Vice Chancellors for Research of the Islamic Azad University, Shiraz Branch, who provided the necessary facilities for this research. 


\section{بررسى اثرات يريناتال و نئوناتال نيتريت سديم بر ميزان سرمى اسيد اوريك، اوره، كراتينين و

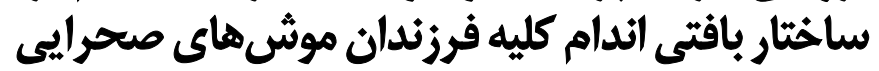

راضيه سنجرى' (1)، "سيد ابراهيم حسينى

1. كروه آموزشى زيست شناسى ،دانشكده علومه واحد شيراز، دانشكاه آزاد اسلامى، شيراز، ايران.

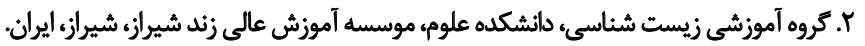

\section{حكיe}

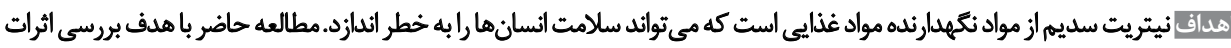

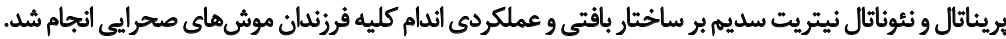

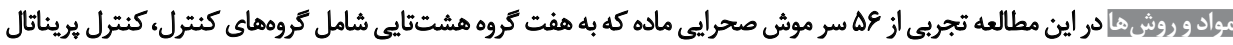

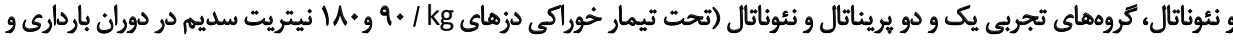

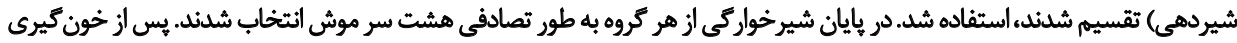

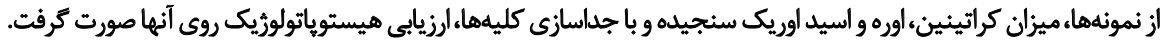

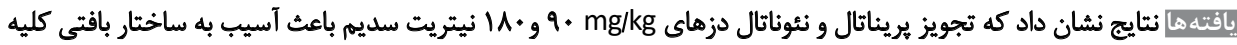

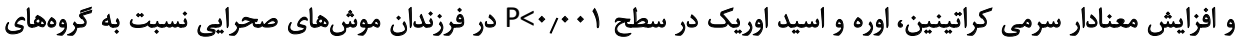

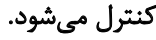

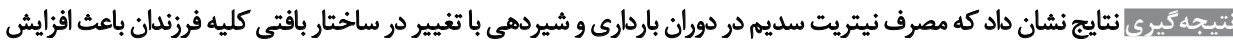

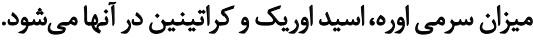

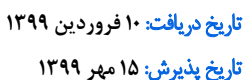

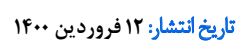

كليدوإوهاو

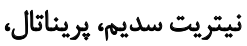

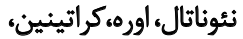
اوريك أسيد

كوشتى، فساد به دليل آلودكى هاى ميكروبى نيز مي ثواند منجر به

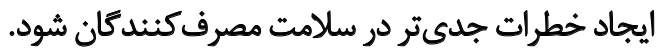

datos بر همين اساس، به نظر هيرسد استفاده از موادى مئاسب

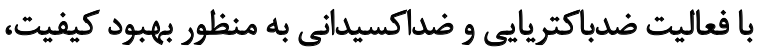

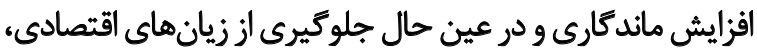

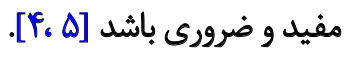

از تركيبات نيتراتي و نيتريتي عمدناً به منظور تثبيت رنك

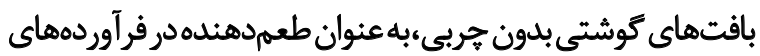

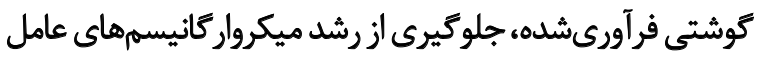
فساد و مسموميت غذايى استفاده مي شوندئ [9] نيتراتها و نيتريتها از كليديثرين افزودنيها در توليد

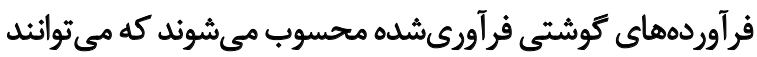

فر آور دهاي نيمهآماده كوشتي كه در شرايط يخجال نكَهدارى

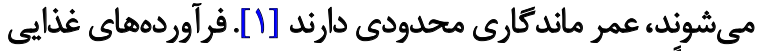

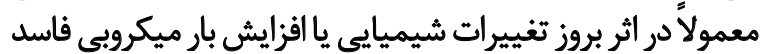

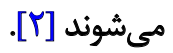
وجود غُلظت بالاي نيترات در محيطهاي آبي، بهخصوص

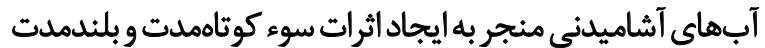

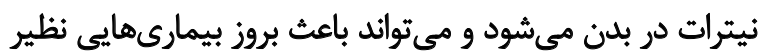

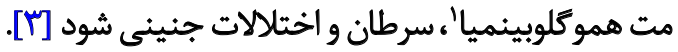
علاوهبر اثر اكسيداسيون هربي هادر كاهش كيفيت فرآوردهاي

1. Methemoglobinemia (MetHb)

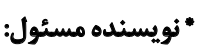
دكتر سيد ابراهيم حسينى نشائى: شيراز، موسسه آموزش عالى آئى زئد شيراز، دانشكده علوم، كروه آموزشى زيستشناسى. ت تلفن: بست الكترونيكي: ebrahim.hossini@yahoo.com 
ساختارهاى بافتى و عملكردى شخص مصرفكنينده يرداخته است

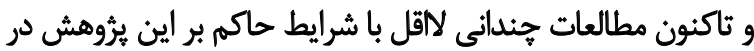

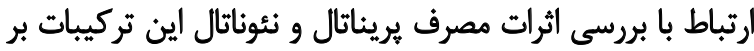

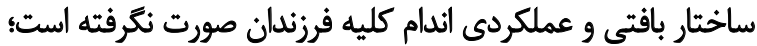

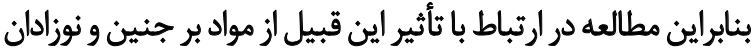

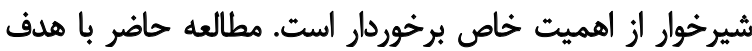

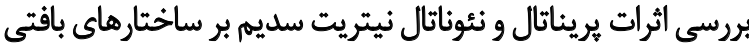

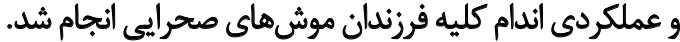

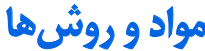

اين مطالعه تجربى روى هوهر سروش صحرايى ماده نراد ويستار

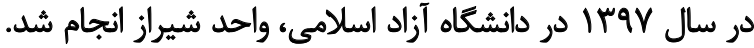

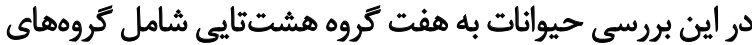

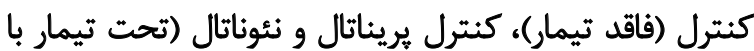

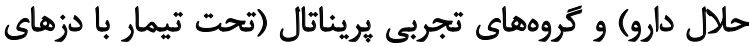

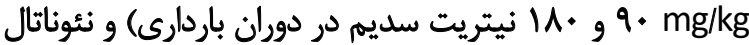

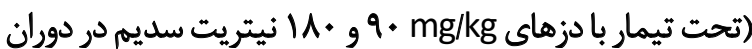

$$
\text { شيردهى) تقسيم شدند استفاده شد. }
$$

در اين مطالعه، تمام تجويزها به صورت كاوارً انجام شد. جهت

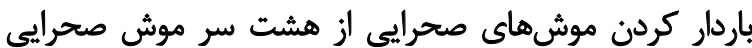

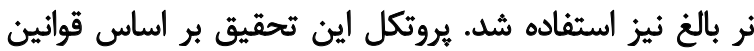

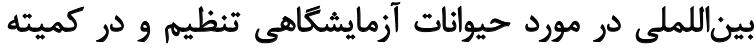

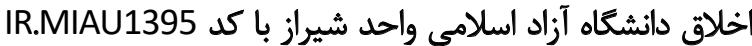

$$
1016 \text { به تصويب رسيد. }
$$

در اين بررسى، حيوانات كروههاي بريناتال از روز اول باردارى

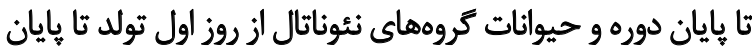

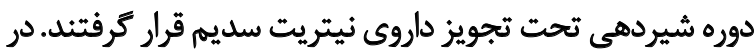

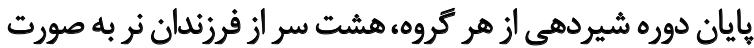

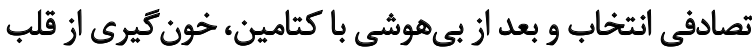

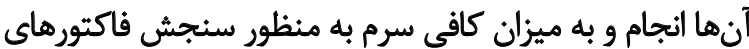

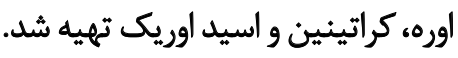

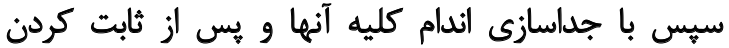

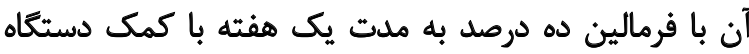

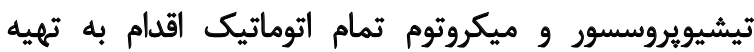

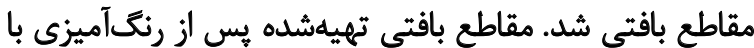

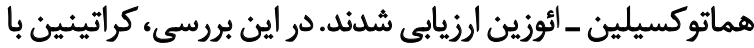

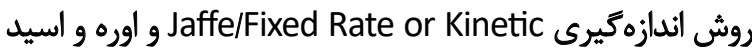

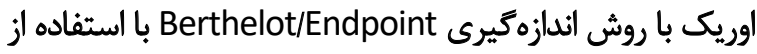
كيتهاي ساخت شركت يارس آزمون اندازمكيرى شدند. در يايان، دادهاى اين مطالعه با استفاده از نرمافزار SPSS نسخه

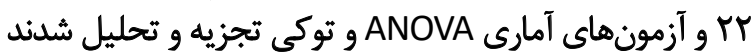

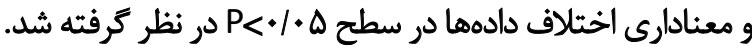

باعث آسيب به عروق خونى، كبد، طحال و ديكر اندامهاى بدن شوند [V]

على غمثم ويثُكىهاى مطلوب ذكرشده براى نيتريتها، اين إين

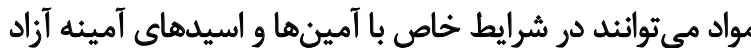

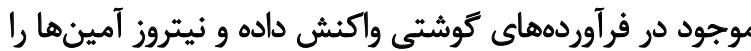

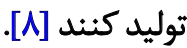

تماس انسان با تركيبات نيتراتى و نيتريتى عمدتاً ناشى از ازئ

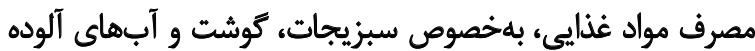

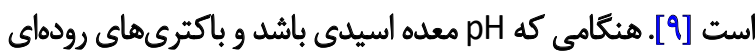
در روده موجود باشند، تركيبات نيتريتى به آسانى با با آمينهاي ثان ثانويه

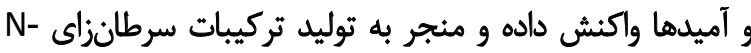
nitrose استفاده فراوان از افزودنىها در مواد غذايى باعث شده كه انسانها

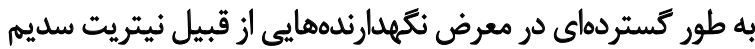

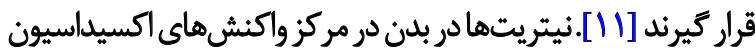

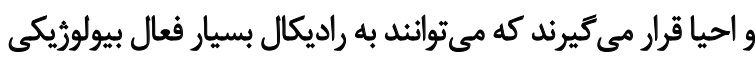

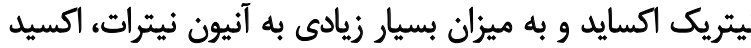

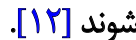

يروكسى نيتريت (-ONOO) حاصل از تركيبات حاوى نيتريت و

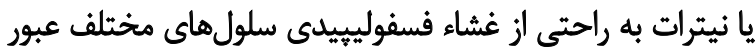

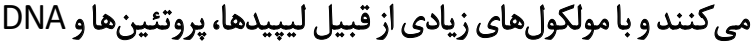

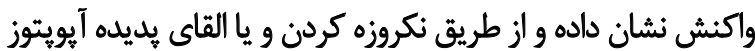

منجر به مرك سلولى مىشوند [باد).

ديروكسى نيتريت و نيتريك اكسيد به وسيله مكانيسمهاى

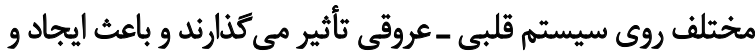

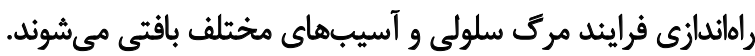

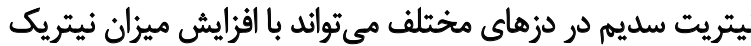

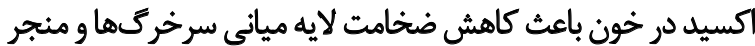

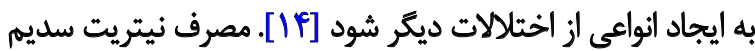

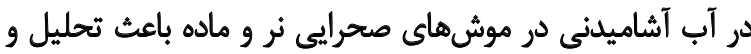

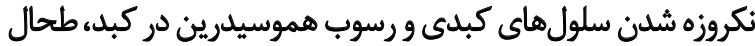

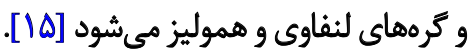
نيتريثها ونيتراتها ييشساز راديكال هاى نيتريكاكسيد (NO)

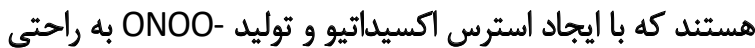

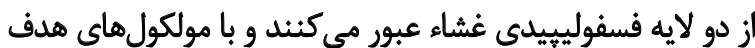

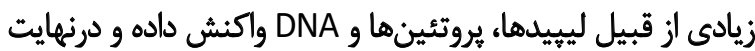

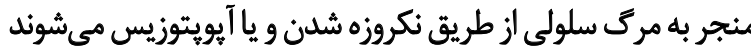

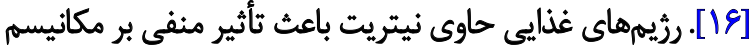

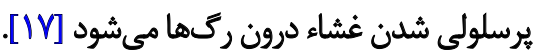

با توجه به آنكه بيشتر مطالعاتى كه روى مواد نكهدارنده، از

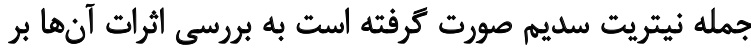


جدول ا. ميانكين و انحراف استاندارد فاكتورهاى كليوى در فزئدان حيوانات كروهاى يريناتال

\begin{tabular}{|c|c|c|c|}
\hline \multicolumn{3}{|c|}{ ميانغين+انحراف معيار } & \multirow[b]{2}{*}{ كروه } \\
\hline $\begin{array}{c}\text { نيترورن اوره خون } \\
\text { (mg/dl) }\end{array}$ & $\begin{array}{l}\text { (mg/dl) } \\
\text { (mitits }\end{array}$ & $\begin{array}{c}\text { اوريك اسيد/d) } \\
\text { (mg/d) }\end{array}$ & \\
\hline 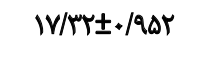 & $. / \% q \pm .1 .58$ & $r / P T \pm 1 / T q$ & كنترل سالم \\
\hline $\mid V /$ TA $\pm V / \vee V \&$ & $. / 4 \cdot 1 \pm \cdot 1.99$ & $r / \Psi \cdot \pm * / M$ & كتترل يريناتال \\
\hline 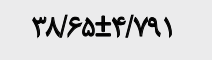 & $. / F T E \pm . / . F A$ & $\Delta / T \cdot \pm \cdot / / q q$ & 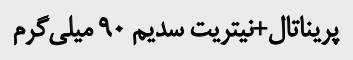 \\
\hline$r q / f+ \pm E / V \Delta q$ & $. / F 9 Y \pm . / . \pi T$ & $\Delta / \varepsilon_{\Delta} \pm V / / f$ & يرينائال +نيتريت سليم •A ميلي كرم \\
\hline
\end{tabular}

أن

قبيل احتقان و خونريزىهاى منتشر، آسيب به ساختار لولههاى

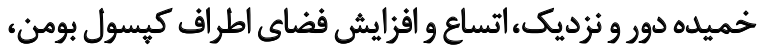

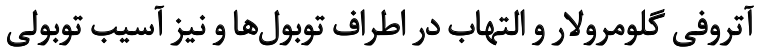

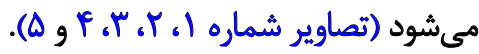

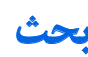

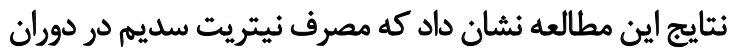

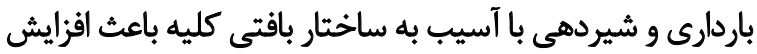

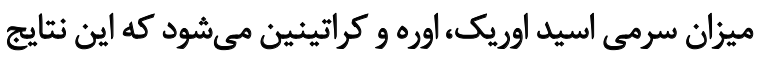

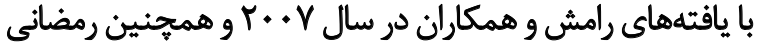

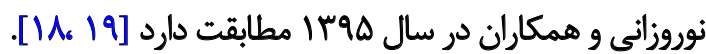

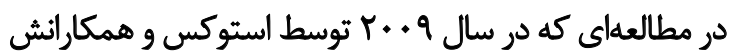

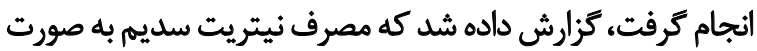

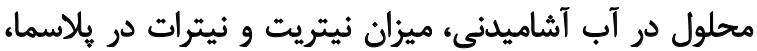

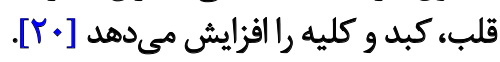

يافتهن

نتايج اين بررسى نشان داد كه مصرف نيتريت سديم در دزهاى

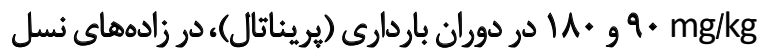

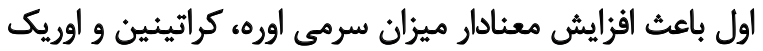

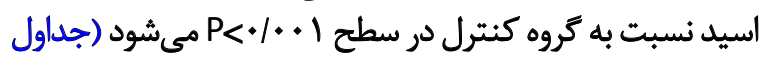

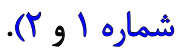

همجنين نتايج اين بررسى نشان داد كه مصرف نيتريت سديم در دزهاى mg/kg •9 و • • إن در دوران شيردهى (يريناتال)،

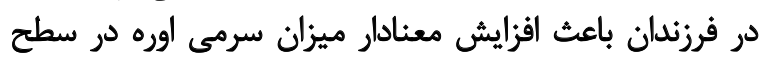

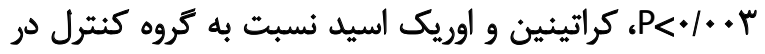

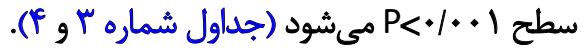

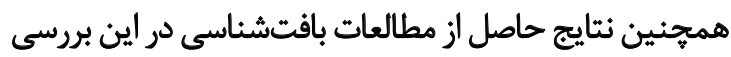

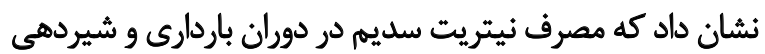

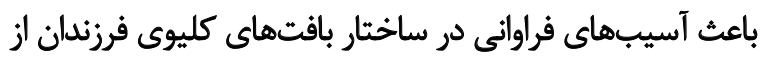

جدول T. نتايج آزمون ANOVA جهت بررسى اثر نيتريت سديهم با دزهاى مختلف بر فاكتورهاى كليوى در فرزندان حيوانات كروههاى بريئاتال

\begin{tabular}{|c|c|c|c|c|c|c|}
\hline سطح معنادارى & $\mathbf{F}$ & ميانئين مربعات & df & مجموع مريعات & \multicolumn{2}{|c|}{ فاكتورها } \\
\hline \multirow[t]{3}{*}{$.1 . .1$} & TQ/१T & ATQ/IDI & $r$ & IAAVFEAT & بين كروهها & \\
\hline & & IV/RVA & rA & $P q F / 9 W$ & درون كروهى & اوره \\
\hline & & & m & $r+A Y / F T q$ & كل & \\
\hline \multirow[t]{3}{*}{$.1 .+1$} & F/gAF & .1 .10 & $r$ & $.1 .4 f$ & يين كروهها & \\
\hline & & $+\infty$ & ra & $\cdot / \cdot A V$ & دونك كروهى & كراتينين \\
\hline & & & M &.$/ M H$ & كل & \\
\hline \multirow[t]{3}{*}{$.1 . .1$} & V/TAS & $81.8 \mathrm{~V}$ & $r$ & Wr.. & بين كروهها & \\
\hline & & /ArE & MA & $m / r^{\prime} \cdot \Delta$ & درون كروهى & اوريك اسيد \\
\hline & & & M & $f y / 8+8$ & كل & \\
\hline
\end{tabular}


جدول r. ميانكين و انحراف استياندارد فاكتورهاى كليوى در فرزندان حيوائات كروههاى نئوناتال

\begin{tabular}{|c|c|c|c|}
\hline \multicolumn{3}{|c|}{ ميانكين ثانحراف معيار } & \multirow{2}{*}{ فاكتورها } \\
\hline الوره (mg/dl) & كراتينين (mg/dl) & اوريك اسيد (mg/dl) & \\
\hline IV/TYI+/9D & $. / 4 q \pm .1 .8$ & $\Delta / r T \pm V / R q$ & كنترل سالم \\
\hline$r m / q r \pm I r / \Delta q$ & $\cdot / r \cdot \pm \cdot 1 \cdot v$ & $T / Y V \pm I / M I$ & كتترل نثونانال \\
\hline$m / \pi r \pm 1 / q \pi$ & $1 / H E \pm+1+r$ & $\Delta / V I \pm 1 / 9 \Delta$ & ئئوناتال +ئيتريت سليم +و ميلى كرم \\
\hline$r q / r q \pm 1+/ \Delta q$ & $1 / 48 \pm+1 \cdot f$ & $ه / 19 \pm • / q \Psi$ & نئونانال +نيتريت سديم +1 ا ميلى كرم \\
\hline
\end{tabular}

انو

جدول F. نتايج آزمون آناليز واريانس يكراهه جهت بررسى اثر نيتريت سديهم با دزهاى مختلف بر فاكتورهاى كليوى در فرزندان حيوائت كروههاى نئوناتال

\begin{tabular}{|c|c|c|c|c|c|c|}
\hline سطع معناداري & $\mathbf{F}$ & ميانئين مريعات & df & مجموع مريعات & \multicolumn{2}{|c|}{ فاكتورها } \\
\hline \multirow[t]{3}{*}{.$/ . . r$} & Q/9TV & EAT/MTT & $r$ & 19ANIEE & بين كروهها & \\
\hline & & $11 . / 1 \pi T$ & ru & $r \cdot \Lambda r / v+1$ & درون كروهى & نيترونُن اوره خُون \\
\hline & & & M & $\Delta .+Y / A V \Delta$ & كل - ن & \\
\hline \multirow[t]{3}{*}{$+1++1$} & $11 / \Delta r$. & (1. & r & $.11 \cdot 9$ & بين كروهها & \\
\hline & & $\%$ & rA & $.1 \cdot 19$ & درون كروهى & كراتينين \\
\hline & & & r & .114 & كل - ا & \\
\hline \multirow[t]{3}{*}{$.1 . .1$} & $11 / \cdot 11$ & IV/ADT & $r$ & $\Delta H / A \Delta A$ & بين كروهها & \\
\hline & & WET. & rA & Pa/ret & درون كروهي & اوريك اسيد \\
\hline & & & M & १९/Tा। & كل & \\
\hline
\end{tabular}

أنّواتث

مطالعات انجامشده، مشخص شده است كه آسيبهاي هارانشيم كليوى باعث افزايش غلظت سرمى نيتروثن اوره خون (BUN)،

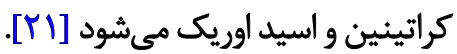
همسو با نتايج هيستوياتولوزيك اين بررسى در مطالعه اشرفى ني

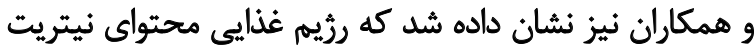

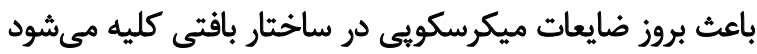

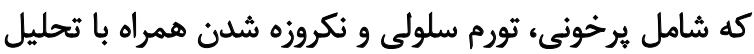

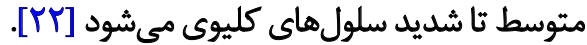

همسو با نتايج حاصل از اين بررسى، در يك مطالعه ديكر

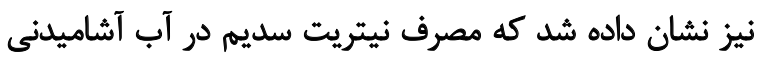

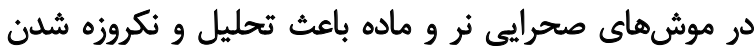

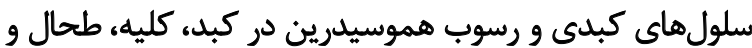

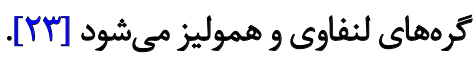

به علاوه، در مطالعات محسنى كوجصفهانى و همكاران نشان

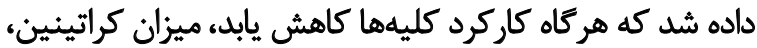

از آنجا كه نيتريت سديم در بلن باعث ايجاد استرس اكسيداتيو

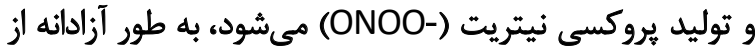

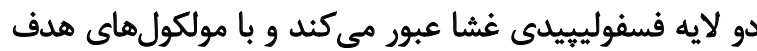

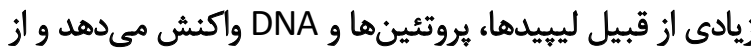

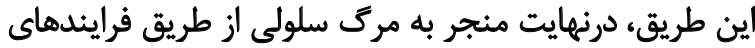

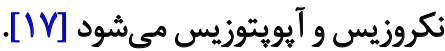

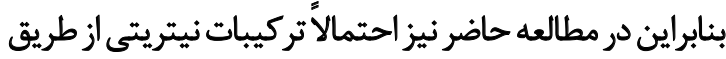

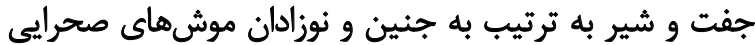

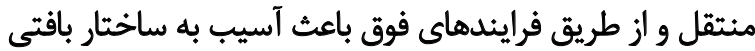

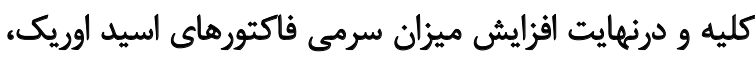
اوره و كراتينين شده است. همجحنين نشان داده شده كه اندام كليه به عنوان محل اصلى

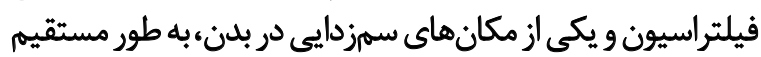

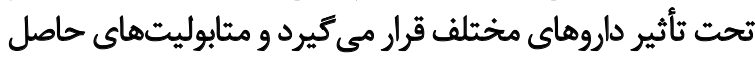

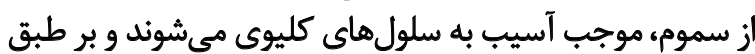



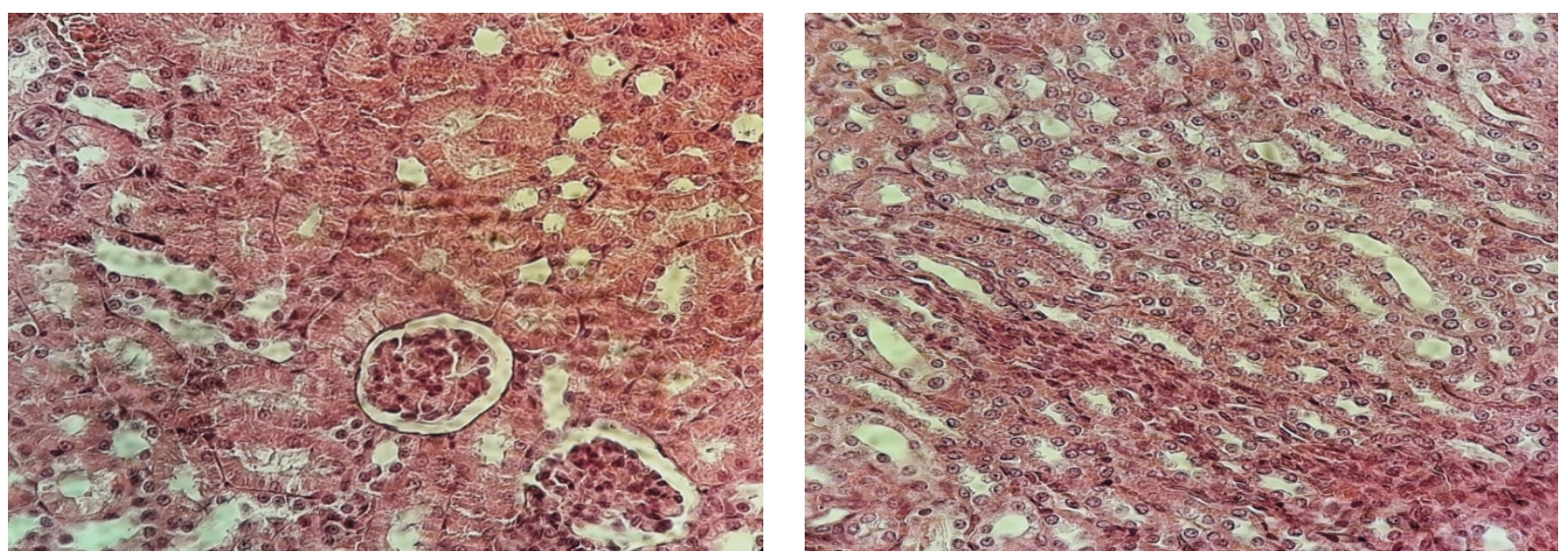
انو

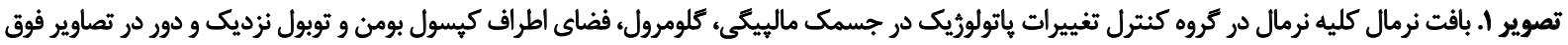

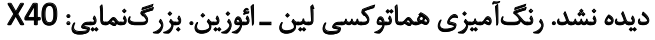
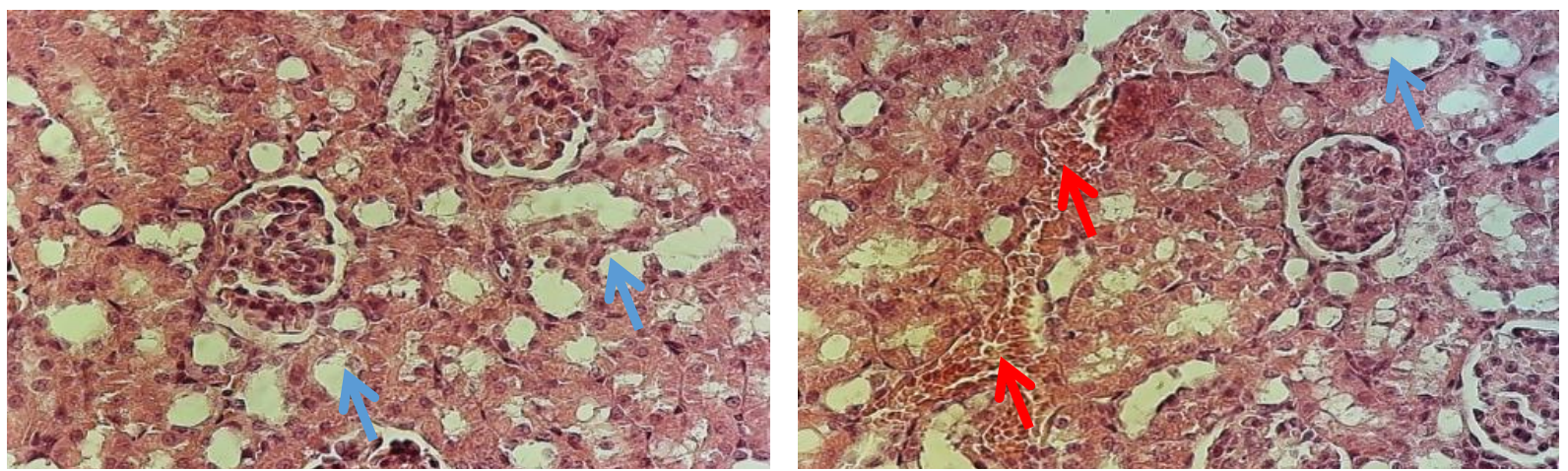

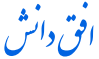

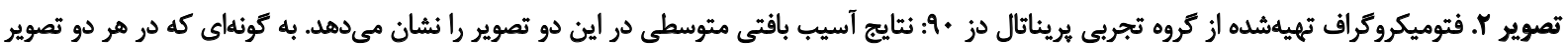

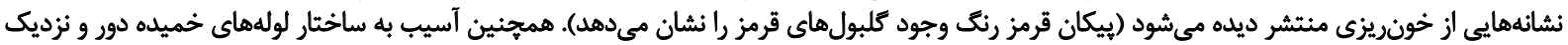

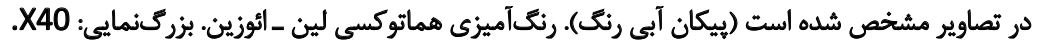
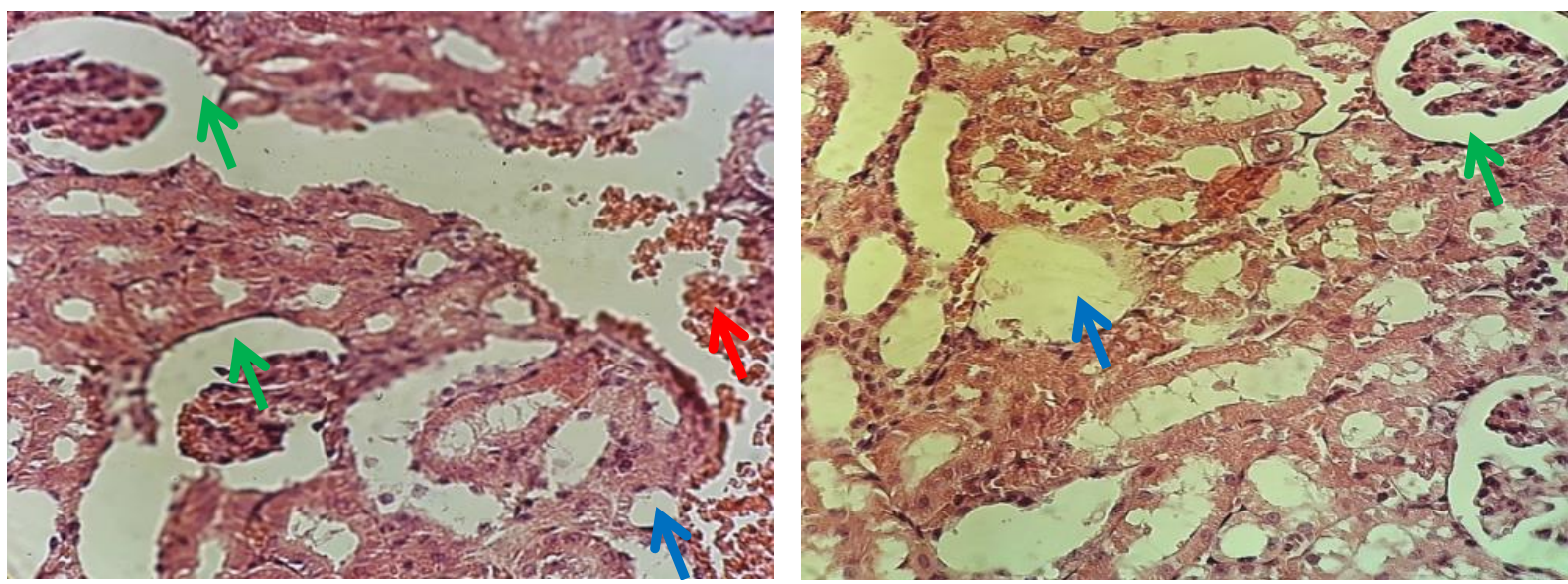

انهّر

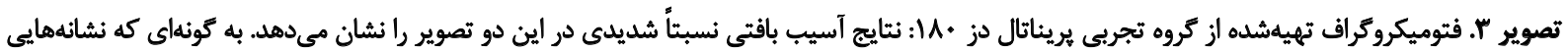

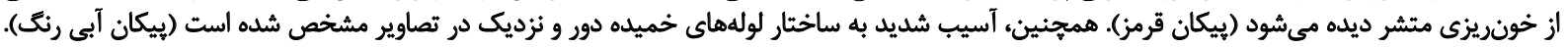

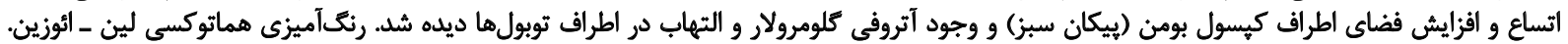
بزرئمايي: X40. X X X 

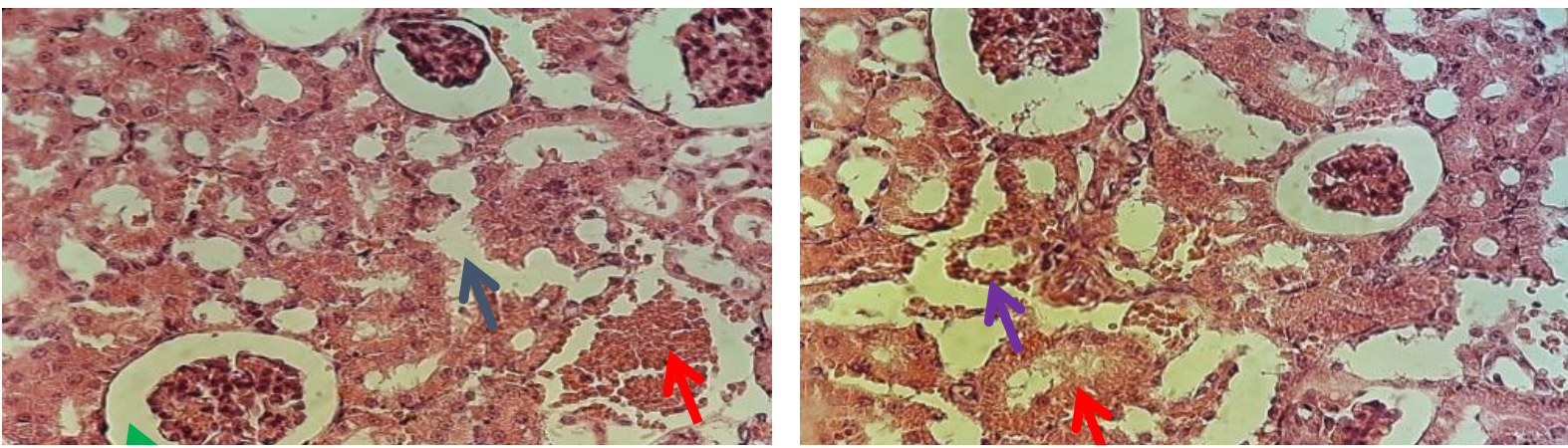
إنّان

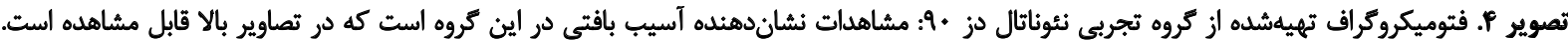

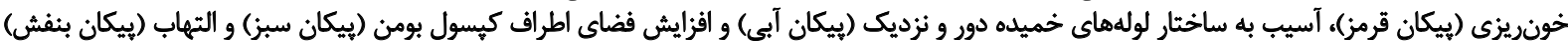

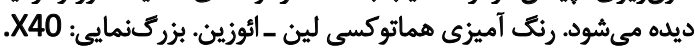
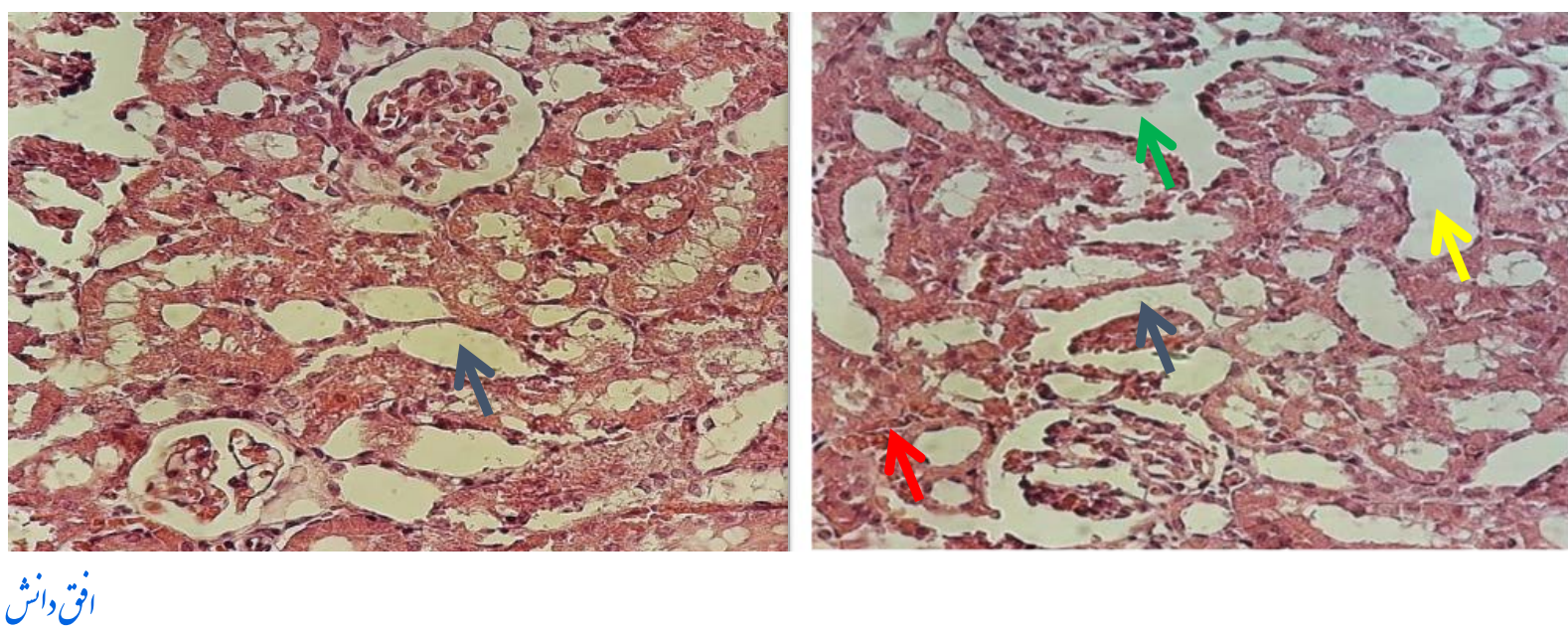

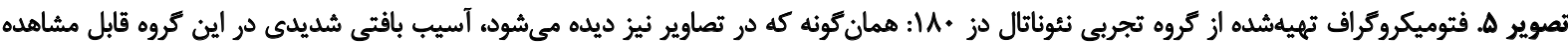

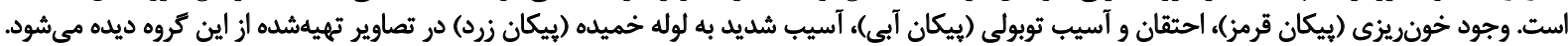

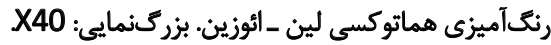

$$
\text { نتيجنميرى }
$$

نتايج اين مطالعه نشان داد كه مصرف نيتريت سديم در دوران

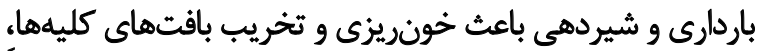

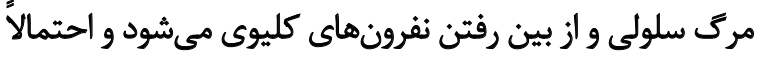

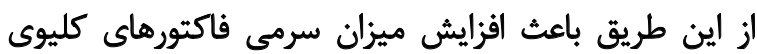

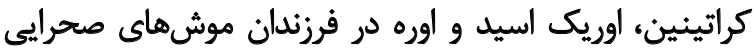

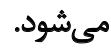

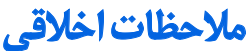

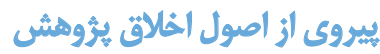

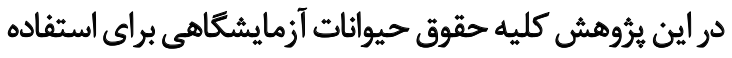

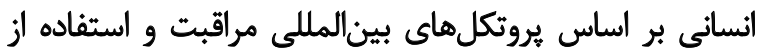

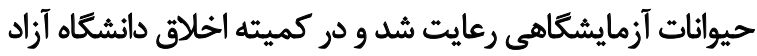

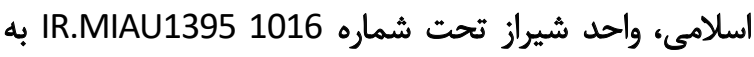

اوره و اسيد اوريك در خون افزايش مىيابد [YF].

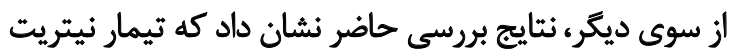

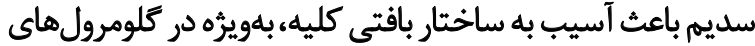

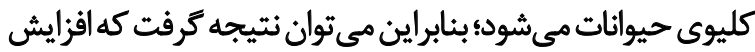

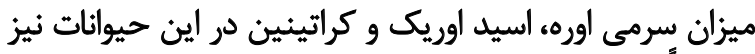

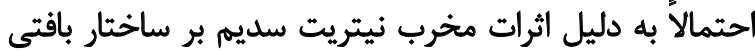

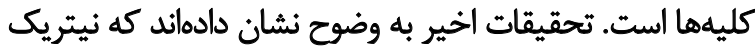

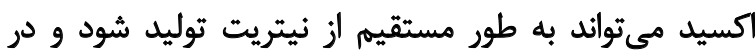

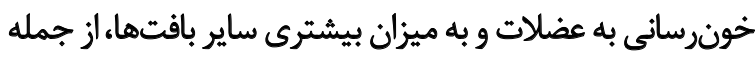

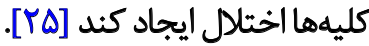

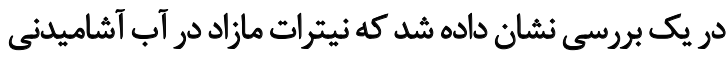

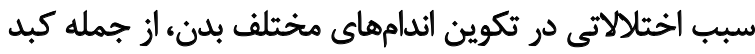

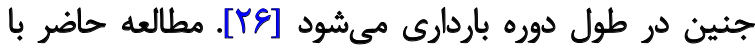

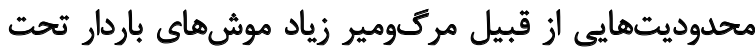

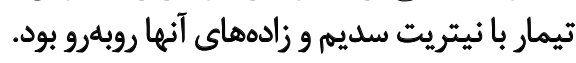




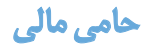

اين تحقيق هيج كونه كمك مالى از سازمانهاي تأمين مالى در باري

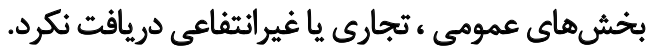

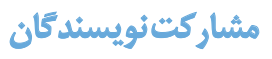

هر دو نويسنده مقاله حاضر در همه موارد با هم مشاركت

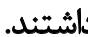

$$
\text { عأق }
$$

بنابر اظهار نويسندكان اين مقاله تعارض منافع ندارد.

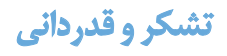

نويسندكان مقاله بر خود واجب ميى دانند ثا از همكاران محترم

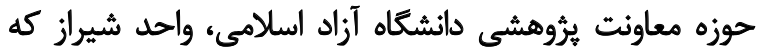

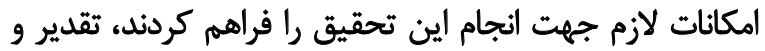
تشكر به عمل آورند. 


\section{References}

[1] Mielnik MB, Aaby K, Skrede G. Commercial antioxidants control lipid oxidation in mechanically deboned turkey meat. Meat Science. 2003; 65(3):1147-55. [DOI:10.1016/S0309-1740(02)00345-5]

[2] Sebrank JG, Sewalt VJH, Robbins KL, Houser TA. Comparison of a natural Rosemary extract and $\mathrm{BHA} / \mathrm{BHT}$ for relative antioxidant effectiveness in pork sausage. Meat Science. 2005; 69(2):289-96. [DOI:10.1016/j.meatsci.2004.07.010] [PMID]

[3] Mary H, Ward Theo M, dek K, Levallois P, Brender J, Gulis G, et al. Workgroup Report: Drinking-water nitrate and health-recent findings and research needs. Environmental Health Perspectives. 2005; 113(11): 16071614. [DOI:10.1289/ehp.8043] [PMID] [PMCID]

[4] Abdel-Hamied AA, Nassar AG, El-Badry N. Investigations on antioxidant and antibacterial activities of some natural extracts. World Journal of Dairy \& Food Sciences. 2009; 4(1):1-7. https://www.cabdirect.org/cabdirect/abstract/20103317582

[5] Georgantelis D, Ambrosiadis I, Katikou P, Blekas G, Georgakis SA. Effect of rosemary extract, chitosan and $\alpha$-tocopherol on microbiological parameters and lipid oxidation of fresh pork sausages stored at $4^{\circ} \mathrm{C}$. Meat Science. 2007; 76(1):172-81 [DOI:10.1016/j.meatsci.2006.10.026] [PMID]

[6] Yin MC, Cheng WS. Antioxidant and antimicrobial effects of four garlicderived organosulfur compounds in ground beef. Meat Science. 2003; 63(1):23-8. [DOI:10.1016/S0309-1740(02)00047-5]

[7] Juibar F, Tavakoli kazerooni A, Ghorbani Ranjbary A. [Histopathological effects of sodium nitrite on the spleen of male and female rats (Persian)]. Iranian South Medical Journal. 2015; 17(6):1160-7. http://ismj. bpums.ac.ir/article-1-632-en.htm

[8] Honikel K-O. The use and control of nitrate and nitrite for the processing of meat products. Meat Science. 2007; 78(1-2):68-76. [DOI:10.1016/j. meatsci.2007.05.030] [PMID]

[9] Cockburn A, Brambilla G, Fernández ML, Arcella D, Bordajandi LR, Cottrill $B$, et al. Nitrite in feed: From animal health to human health. Toxicology and Applied Pharmacology. 2013; 270(3):209-17 [DOI:10.1016/j. taap.2010.11.008] [PMID]

[10] Lundberg JO, Weitzberg E, Gladwin MT. The nitrate-nitrite-nitric oxide pathway in physiology and therapeutics. Nature Reviews Drug Discovery. 2008; 7(2):156-67. [DOI:10.1038/nrd2466] [PMID]

[11] Ismail AETM, Moustafa AM, Abd El-Rhman B G. Microscopic studies of the effect of some food additives on the kidney of albino rat. The Egyptian Journal of Hospital Medicine. 2003; 12(1):12-27. [DOI: 10.12816/ EJHM.2003.18241]

[12] Dezfulian C, Raat N, Shiva S, Gladwin MT. Role of the anion nitrite in ischemia-reperfusion cytoprotection and therapeutics. Cardiovascular Research. 2007; 75(2):327-38. [DOI:10.1016/j.cardiores.2007.05.001] [PMID] [PMCID]

[13] Stokes KY, Dugas TR, Tang Y, Garg H, Guidry E, Bryan NS. Dietary nitrite prevents hypercholesterolemic microvascular inflammation and reverses endothelial dysfunction. American Journal of Physiology Heart and Circulatory Physiology. 2009; 296(5):H1281-8. [DOI:10.1152/ajpheart.01291.2008] [PMID]

[14] Juibar F, Khatamsaz S, Ghorbani Ranjbry A. [Investigating sodium nitrite effect on blood nitric oxide and histopathologic changes on pulmonary artery in adult male rats (Persian)]. Journal of Shahid Sadoughi University of Medical Sciences and Health Services. 2013; 21(5):609-18. https://www.sid.ir/en/Journal/ViewPaper.aspx?ID=356450
[15] Roussel AM, Hininger I, Benaraba R, Ziegenfuss TN, Anderson RA Antioxidant effects of a cinnamon extract in people with impaired fasting glucose that are overweight or obese. Journal of the American College of Nutrition. 2009, 28(1):16-21. [DOI:10.1080/07315724.200 9.10719756] [PMID]

[16] Li J, Li W, Su J, Liu W, Altura BT, Altura BM. Peroxynitrite induces apoptosis in rat aortic smooth muscle cells: Possible relation to vascular diseases. Experimental Biology and Medicine (Maywood, N.J.). 2004; 229(3):264-9. [DOI:10.1177/153537020422900307] [PMID]

[17] Matthew JA, Evie C, Mark TG, Edith T, Brian SZ. Dietary nitrates and nitrites modulate vascular intimal hyperplasia. Journal of the American College of Surgeons. 2010; 211(3):S138. DOI: [DOI:10.1016/j.jamcollsurg.2010.06.368]

[18] Ramezani Noroozani F, Ojinejad D, Ghorbani Ranjbary A. [Effects of sodium nitrite on Liver enzymes and histological structure of liver in streptozotocin-induced diabetic rats (Persian)]. Journal of Mazandaran University of Medical Sciences. 2017; 26(144):171-9. https://www.sid. ir/en/journal/ViewPaper.aspx?id=536705

[19] Remmesh B, Viswanathan P, Pugalendi KV. Protective effect of Vmbeliferone on membranous fatty acid composition in streptozotocin-induced diabetic rats. European Journal of Pharmacology. 2007; 566(1-3):231-9. [DOI:10.1016/j.ejphar.2007.03.045] [PMID]

[20] Stokes KY, Dugas TR, Tang Y, Garg H, Guidy E, Bryan NS. Dietary nitrite prevents hypercholesterolemic microvascular inflammation and reverses endothelial dysfunction. American Journal of Physiology. Heart and Circulatory Physiology. 2009; 296(5):1281-8. [DOI:10.1152/ajpheart.01291.2008] [PMID]

[21] Gad SB, Zaghloul DM. Beneficial effects of green tea extract on liver and kidney function, ultrastructure, lipid profile and hematological parameters in aged male rats. Global Veterinaria. 2013; 11(2):191-205 [DOI: 10.5829/idosi.gv.2013.11.2.7472]

[22] Ashrafy E, Hosseini SE. [Protective effects of Cinnamon hydro-alcoholic extract on liver lesions induced non-alcoholic fatty liver disease and sodium nitrite poisoning in adult male rats (Persian)]. Journal of Shahrekord University of Medical Sciences. 2018; 19(6):13-23. http://eprints. skums.ac.ir/6908/

[23] Roussel A-M, Hiniger I, Benaraba R, Ziegen fuss TN, Anderson RA. Antioxidant effects of a Cinnamon extract in people with impaired fasting glucose that are over weight or obese . Journal of the American College of Nutrition. 2009; 28(1):16-21. [DOI:10.1080/07315724.2009.1071975 6] [PMID]

[24] Mohseni Kouchesfhani H, Khoshnoud S, Nabiuni M. [Evaluation of protective effect of hydro-alcoholic extract of raspberry fruit on the methotrexate-induced nephrotoxicity in male Wistar rats (Persian)] Razi Journal of Medical Sciences. 2015; 22(138):78-87. http://rjms.iums. ac.ir/article-1-4089-en.htm

[25] Zand J, Lanza F, Garg HK, Bryan NS. All-natural nitrite and nitrate containing dietary supplement promotes nitric oxide production and reduc es triglycerides in humans. Nutrition Research (New York, N.Y.). 2011 31(4):262-9. [DOI:10.1016/j.nutres.2011.03.008] [PMID]

[26] Ghoreishi M, Nabuni M, ShiraviA A, Rostami M, Karimzadeh Barde L. [The effects of the water nitrate on the histology and immunohistology of the liver development in NMRI Mice Fetus (Persian)]. Journal Of Animal Research (Iranian Journal of Biology).2016;29(2):215-222. https:// animal.ijbio.ir/article 832.html?lang=en 
This Page Intentionally Left Blank 